\title{
What's in a name! \\ That which we call a course by any other name would smell as sweet
}

\author{
James H. Strain \\ Victoria College \\ Alistair Inglis \\ Victoria University of Technology
}

\begin{abstract}
Following a major revision of course content, the former Graduate Diploma in Educational Technology conducted at Victoria College was re-accredited in December 1989 as a Graduate Diploma in Instructional Design and Technology. This paper will examine the significance of the course's name change and explore the distinctions identified between the role profile of an instructional designer and an educational technologist. The authors will outline some of the fundamental changes necessary in providing a graduate diploma program for instructional designers as compared to educational technologists.
\end{abstract}

\section{Converging technologies}

The advance publicity for Ed Tech '90 said, in explaining the theme of this conference,

"... the 1990's will be a decade of convergence, when disparate technologies and methodologies will come together to offer a more complete educational experience."

No doubt the author of the statement was thinking of the very significant convergences we are now seeing in the "hard" technologies such as the bringing together of voice, data and video processing through digitisation, or the union of computer and video graphics in multimedia computing, or the combining of graphic production and page makeup in desktop publishing. However, this paper looks at convergence of another kind: the 
convergence of two "soft" technologies, educational technology and instructional design.

These two process technologies have, of course, always been quite closely related. Indeed, it is well known that what in one country is called educational technology may in another be called instructional design. However, the separation which most people will readily acknowledge did exist between the study of the applications of instructional media and the study of the design of instruction using the media left the practitioners of either technology with an incomplete range of solutions for solving client problems.

In recent years the coalescence of the hard technologies has started to bring a coalescence also of the soft technologies. Instructional designers starting to work in the field of computer-based training have had to become expert in the characteristics and operation of computer-based training systems and computer-based training specialists who have arrived in the field from a delivery systems background have quickly recognised the need for instructional design skills.

At Victoria College, a parallel transition has just taken place. Recognising the growing importance of instructional design, particularly in the industrial training field, the College has just recently reaccredited the Graduate Diploma in Educational Technology as a Graduate Diploma in Instructional Design and Technology. The reaccredited course is being offered for the first time in 1990.

This paper discusses some of the background behind the decision to make the change, looks more closely at the historical relationship between educational technology and instructional design and gives an overview of the new course and the response it has so far received.

The events that have led up to this development have been the recent government initiatives in the industrial training sector.

\section{The "new face" of industry training}

In late 1988, the Minister for Employment, Education and Training released a discussion paper entitled Industry Training in Australia - The Need for Change. In it he signalled the government's intention to make training a high priority for its industry policy. Speaking with regard to the types of changes to training policy he saw as being necessary, he said: "The Government is committed to ensuring that there is a substantial improvement in industry's training effort. This will require more responsive and better quality training as well as more expenditure on training." 
In May 1989, after entering into extensive consultation with industry, the Government announced its intention to introduce an enterprise-based training levy. The levy, subsequently renamed the "Training Guarantee", was approved by Federal cabinet in September 1989 and came into effect from 1 July 1990. The Training Guarantee Act requires employers with an annual national payroll of $\$ 200,000$ or more to spend the equivalent of $1 \%$ of this payroll on "eligible training expenditure" in 1990-91 and 1991-92. This will rise to $1.5 \%$ per annum from 1 July 1992.

Introduction of the Training Guarantee has made training a central concern for all medium to large enterprises. Although companies have the right to determine how they direct their training expenditure, to be recognised as "eligible expenditure", a training program must satisfy the following criteria:

- the objective of the program, and the means of achieving and evaluating the achievement of the objectives, must be clearly identified before the start of the program;

- the program must be designed or approved by a person who is appropriately qualified to design or approve a training program of the relevant type;

- the method of evaluation of the program must be identified before the program begins.

Proclamation of the Training Guarantee Act has, in a stroke, created a major market for specialists in instructional design. By adopting a competency-based approach to training, the government has presented companies with the need to adopt the systematic application of well-tested instructional principles, rather than rely on intuitive, informal approaches so typical of training programs today. To meet these requirements companies will be seeking staff with the skills to analyse instructional (or training) needs, develop programs to meet these needs and evaluate the program against set competency standards; in other words staff skilled in instructional design.

While employers will seek to earn the maximum credit for training programs they already run and some employers will seek to meet the new requirements "on the cheap" by claiming credit for expenses that are only indirectly associated with training such as the costs of travel and accommodation associated with attendance at conferences, there are still likely to be a large number of firms that will take this opportunity to try to put in place effective on-going programs of staff development. For these companies, finding trained staff to undertake this task will be one of the greatest difficulties in developing a suitable training program.

Many former teachers with educational technology qualifications have become trainers and found that they could make very worthwhile contributions to the training programs of business and industry. The type 
of contribution that they made was greatly determined, of course, by their previous job orientation. The perspective they brought with them was that of an educational technologist. Recently, industry has been seeking staff who have instructional design skills specifically. However, the question that has to be asked is: "Is there something more to instructional design than educational technology with a change of name?"

To those who are outside the field of instructional design, and even to many of those who are recent recruits to the field, the distinction between educational technology and instructional design is difficult to describe. That there is a difference most people seem prepared to accept. Just what the difference is by no means clear to all.

To understand the distinction, it is helpful to trace the origins of instructional design.

\section{The three phases in the development of instructional design}

\section{Phase 1: A response to the perceived need for more effective training methods}

For an account of the early history of instructional design we can turn to one of the fathers of the discipline, the American academic and co-author with Robert Gagne of the text Instructional Design Principles, Leslie Briggs. Writing in a special anniversary issue of Educational Technology, published in 1980, Briggs traced the first thirty years of instructional design.

Briggs points out that many of the early instructional designers were trained, like him, as psychologists but they brought together skills from a variety of disciplines: media, communication and curriculum development, among others. The factor that led to the emergence of this new discipline was the need which the armed forces had perceived for greatly improving the effectiveness of training methods.

Throughout the sixties the term "educational technology" appears to have been the term of choice rather than "instructional design" for referring to the field concerned with the development of instruction according to systematic principles. A number of journals were launched with "educational technology" in their titles; for example Educational Technology, Journal of Educational Communications and Technology, and British Journal of Educational Technology. Those who regarded themselves as educational technologists were quick to point out that the "technology" to which they referred was not the hardware upon which their discipline depended but the series of empirically tested principles for developing materialsmediated instruction. Most of these principles were not restricted to materials-mediated instruction but were extended to any instruction in a 
reproducible form, since the application of these principles enabled the effectiveness of such instruction to be tested.

It is not clear exactly when the term "instructional design" began to emerge as the term of choice to describe the process of instructional principles to bear on the design process.

In the preface to his anthology, Instructional Design: Readings, published in 1971 David Merrill used the following quotation to try to explain what was meant by the term "instructional design":

We view instructional design as being essentially a well-disciplined and experimental approach to instruction, characterised by explicitness, by sophisticated behavioural analysis, and by careful control of stimuli and student response and organised to elicit behavioural sequences that have been empirically determined

The quotation had come from a paper by Phil Lange published six years earlier, but it was a definition to which, according to Merrill, most of the authors represented in the collection would have subscribed.

The mid sixties was the period during which the popularity of programmed learning reached its zenith. It is not surprising, therefore, to find that this early interpretation of instructional design should have such a behaviourist ring to it. Over the ensuing years, as cognitivism replaced behaviourism in educational psychology, instructional design theory developed to keep pace.

The field of instructional design began to develop a distinct "personality" in the early seventies. The term "instructional design" began to creep into the literature to distinguish between the application of well-tested principles of instruction to the design of learning packages and the more general principles of media selection and use. However, for several years, instructional design was recognised as a separate discipline only in North America. In Britain and elsewhere, the term "educational technology" continued to be used to describe both the educational applications of audiovisual technologies as well as the systematic application of the principles of educational psychology to the design of instruction. However, it needs to be recognised that the practice of educational technology in Britain generally did not reach the depth that instructional design reached in the US.

In the United States, the practice of instructional design continued to develop in the armed forces. However, many of the "founding fathers" of instructional design moved out of the defence forces and into education. Briggs moved to Florida State University in 1968 where he again teamed up with Robert Gagne with whom he had previously worked in the Air 
Force Personnel and Training Research Centre. The academic institutions then began to share in the development through major defence-funded projects.

Foremost amongst the institutions that began to establish their own research groups were Florida State University, Brigham Young University and the University of Indiana.

\section{Phase 2: Instructional design is "discovered" by distance educators}

Instructional design received a boost in recognition with the establishment of the British Open University. The Open University was initially conceived of as a "University of the Air" but following the completion of a wide-ranging planning study, was given a charter as an institution dedicated to correspondence education. The University saw a central role for educational technology right from the outset and employed a variety of consultants to advise on how this might be achieved.

The University planners created a central support unit as a key component of the new institution to advise and assist staff in the creation of instructional material. This was named the Institute for Educational Technology.

The Open University set a new standard in the design and presentation of instructional materials and set a new pattern for the way in which correspondence institutions operated. Around the world, country after country adopted the Open University model and with it the commitment to instructional design.

In Australia, the establishment of distance education at the higher education level had predated the Open University by more than half a century. The first institution to recognise instructional design as a distinct specialisation within education by appointing staff specifically to work in this area was the Royal Melbourne Institute Technology. This was in 1976. Deakin University, which had at that stage only been established was also concerned to place a major emphasis on instructional design. However, the institution that eventually took the lead in this field and conferred academic credibility on the application instructional design in distance education was Darling Downs Institute of Advanced Education in Queensland.

The decision by the Australian Regional Colleges organisation to press for an understanding that institutions engaged in distance education as a major part of their activities should be expected to employ at least one full time staff member in the area of teaching and learning led to a rapid increase in the emphasis placed on instructional design. New staff were appointed into the area at Warrnambool Institute of Advanced Education, 
Riverina College of Advanced Education, Capricornia Institute of Advanced Education as well as other smaller colleges. Spurred on by the actions of the colleges, the universities involved in distance education followed suit not long afterwards.

Another major expansion in instructional design occurred recently with the establishment of the Distance Education Centres. One of the roles of the Distance Education Centres is to improve the instructional quality of distance education offerings. A recent survey of teaching learning specialists employed by the Distance Education Centres shows that in aggregate the eight centres employ amongst them more than thirty fulltime staff in instructional design.

\section{Phase 3: Computer-based training recognises the need for design skills}

Outside distance education, instructional design has had its greatest impact in the field of computer-based training. The 1980s also saw the rapid development of computer hardware and software to the point where it was possible for sophisticated instructional programs to be developed at reasonable cost by computer. By the late ' $80 \mathrm{~s}$ an impressive range of authoring systems, capable of delivering instruction on personal computers had become available. These included 'Unison', 'Tencore', 'Microcraft Author', 'Coursemaster' and 'Authorware Professional'. In business, industry and education in Australia, these systems have been used increasingly to produce training materials. However, few of the trainers responsible for producing materials have had any previous instructional design training so their efforts have been mainly by trial and error.

With the growth of instructional design in distance education and the interest that has been shown by distance educators in computer-based instruction, a strong link has developed between these two fields and its importance is growing.

\section{How is the relationship between educational technology and instructional design seen today?}

Clearly, the fields of educational technology and instructional design have shared a common origin, but what is their relationship today? Is instructional design a field which bears a proximal relationship to educational technology or does it represent a subset? And what can be said about the respective roles of educational technologists and instructional designers. Do fundamental differences exist between an educational technologist and an instructional designer? Do they fulfil the same role? Do they subscribe to the same theoretical framework? Do they adopt the same methodology? Is an educational technologist readily 
interchangeable with an instructional designer? These are not easy questions to answer.

To those involved in research into instructional design, the emergence of instructional design out of educational technology probably seems like a developmental progression. However, to people who have come into the field, lacking a grounding in educational psychology, instructional design probably seems a quite different field. Without a professional body to define its limits, without a culture, instructional design has tended to become what those who consider themselves to be instructional designers say it is. To an educational psychologist it will appear to be grounded in the psychological principles of instruction, to the communication specialist it will be concerned with the appropriate use of media. The danger in this phenomenon is that instructional design may become a melding of theoretical perspectives without much depth.

The Australian Society for Educational Technology has, of course, made its own contribution to the recognition of instructional design. However, the Society's impact has been muted by the fact that instructional design has been just one of several interest areas for which it caters.

Instructional design primarily focuses on how learners interact with and encode different instructional materials. It is concerned with the structural properties of these materials and how these structural properties can facilitate memorisation, retrieval, transfer and learning. Computer-based training applications and other technology enhanced training systems provide the potential means to do this very well, but they don't provide the necessary knowledge of recent advances in cognitive psychology that form an essential component of modern instructional design theory.

\section{The training of instructional designers in Australia}

Instructional designers working for industry are at a premium. Yet, until the introduction of the Graduate Diploma in Instructional Design and Technology, there were few tertiary programs which provided formal training in instructional design.

A number of institutions, like Victoria College, offered courses in educational technology. However, due to a number of factors including requirements for teacher training qualifications in order to gain admission, and a perception that the courses were principally concerned with the media, these courses attracted only a limited number of applicants from business and industry.

For several years, the three Australian defence forces and a number of large Australian companies have been sending senior training personnel to the United States, particularly to Florida State University, to gain formal 
qualifications in instructional design. There has also been a significant migration of instructional designers from tertiary education into industry, commerce and the defence forces.

Irrespective of how employers interpret the term "instructional design" it is clear that they now recognise it as an important field of training and development, and instructional designers as essential participants in the instructional materials development process.

\section{Designing a course in instructional design}

It was against this background, then, that the Instructional Technology Unit at Victoria College took the decision in 1988 to refocus its Graduate Diploma in Educational Technology so that it became a professional qualification for those wishing to specialise in the field of instructional design.

In order to ascertain how the new course could best serve the training needs of business, industry, government, defence and education, a series of seminars of college staff and representatives of key employment groups were held in late 1988. These seminars generated strong encouragement for the course and helped clarify changes necessary in redeveloping a graduate diploma in educational technology into a graduate diploma in instructional design. In 1989, a new Course Advisory Committee was formed. This committee consisted of representatives from the Victorian Employers' Federation (VEF), RAAF, TAFE, The Australian Institute for Training Development (AITD), a large training consultancy, a bank, a finance company and academia. Significantly, the committee included both professional instructional designers as well as employers of instructional designers.

Throughout 1989, the staff of the Instructional Technology Unit working under the guidance of the Course Advisory Committee created the structure for the new course. Appropriate to its new emphasis on instructional design, it was determined that the course should place greater emphasis on the application of well-founded learning and instructional principles in the design of learning materials and less emphasis on media production skills. It was felt that as media production was largely subcontracted in industrial training, graduates would only require a working knowledge of appropriate media, rather than advanced production skills. It was determined that the systematic design approach to instruction should be included as a core unit of the course and that a related study of learning theories and their applications should be closely integrated with this unit. It was further agreed that recent developments in computer-based training called for the inclusion of a core unit in technology-based training systems and the demand for training personnel competent in the management and evaluation of instructional materials 
required core units in program evaluation and program management. These five of the six core units in the course cover what were identified by the course developers as the major competencies involved in the instructional designer's role.

The sixth core unit is a contracted major project to be developed in conjunction with associated tasks in the units Program Management and Program Evaluation. The Contracted Major Project is seen as the culmination of the product approach to the course and is required to be developed for a client. It is seen as also providing valuable experience for course participants in client negotiations and contracted learning.

In order to complete their course, participants are also required to complete two of four optional media technology units. Although only four optional units are initially included in the course, it was agreed that further optional units will be added whenever appropriate technological developments justify their inclusion in the course.

The new course structure (refer to Table 1) was agreed to, unit contents were developed and the new course was ultimately reaccredited as a Graduate Diploma in Instructional Design and Technology in December 1989.

Table 1: Course Structure for the Graduate Diploma in Instructional Design and Technology
A. CORE UNITS
Systematic Design of Instruction
Theories of Learning and Their Application
Technology Enhanced Training Systems
Program Management
Program Evaluation
B. OPTIONAL UNITS
(students select two)
Producing Video for Training
Graphic and Photographic Visual Design
Presentation Technologies for Instructors
Computer Applications
C. Contracted Major Project

Following a major course promotion, over 80 course enquiries and 57 course applications were received. The course commenced in February 1990 with 48 new part-time participants.

In order to cater for the learning needs of business and industry as well as the traditional educational market, it was necessary to remove the teacher- 
training qualification as a compulsory admission requirement. An analysis of the employment categories of the 48 course participants provides strong support for this decision and general justification for the redirection of the course in response to the increasing demand for instructional design specialists in business and industry. Only 19 of the 48 new course participants have come from the traditional course market of education (Refer to Table 2).

Table 2: Breakdown of enrolments by student's field of employment

\begin{tabular}{lr}
\hline TAFE Colleges & 11 \\
Banking & 5 \\
Finance Companies & 3 \\
Education & 4 \\
RAN Training & 3 \\
Hospitality Companies & 3 \\
Transport Companies & 3 \\
Business (various) & 8 \\
Government (various) & 4 \\
Colleges of advanced education & 4 \\
\hline
\end{tabular}

\section{References}

Department of Employment Education and Training (1988). Industry Training and Australia: The Need for Change. Canberra: AGPS.

Briggs, L. (1980). Thirty years of instructional design: One Man's Experience. Educational Technology, February, 45-50.

International Board of Standards for Training Performance and Instruction (1986). Instructional Design Competencies for Standards. University of Iowa.

Authors: James H. Strain is the Head of the Instructional Design Unit in the Department of Information and Numerical Sciences, Faculty of Applied Science at Victoria College.

Alistair Inglis is Senior Lecturer in Instructional Design and Distance Education from the Educational Research and Development Unit at Victoria University of Technology.

Please cite as: Strain, J. H. and Inglis, A. (1990). What's in a name! That which we call a course by any other name would smell as sweet. Australian Journal of Educational Technology, 6(1), 1-11.

http: / / www.ascilite.org.au/ajet/ajet6/strain.html 